\title{
PENERAPAN PEMBELAJARAN KOOPERATIF MODEL JIGSAW UNTUK MENGATASI KESULITAN BELAJAR SISWA DALAM MENYELESAIKAN PERSAMAAN DAN PERTIDAKSAMAAN NILAI MUTLAK PADA KELAS X TKJ B DI SMKN 3 PALU
}

\author{
Jafar \\ SMKN 3 Palu \\ ujaf.68@gmail.com
}

\begin{abstract}
Abstrak: Permasalahan pokok pada penelitian ini adalah Mengatasi Kesulitan Siswa belajar tentang Persamaan Dan Pertidaksamaan Nilai Mutlak dalam Menentukan Unsur-Unsur Niali Mutlak. Salah satu faktor penyebabnya adalah pembelajaran yang digunakan guru dalam kegiatan pembelajaran tidak melibatkan siswa secara aktif. Untuk memotivasi siswa dalam belajar, maka Model pembelajaran yang menekankan keaktifan dan kerjasama siswa dalam belajar adalah pembelajaran kooperatif model Jigsaw. Tujuan penelitian adalah mendeskripsikan pembelajaran kooperatif model Jigsaw dalam mengatasi kesulitan belajar siswa tentang persamaan dan pertidaksamaan Nilai mutlak untuk menentukan unsur-unsur nilai mutlak. Dalam penelitian tindakan kelas, cara pengumpulan data melalui tes, wawancara dan observasi aktivitas. Desain penelitian ini menggunakan model Spiral Kemmis dan Mc Taggart dengan empat tahap kegiatan yaitu:(1)Perencanaan ;(2)Tindakan ;(3)Observasi ;(4)Refleksi. Setelah penelitian ini dilaksanakan terjadi peningkatan minat dan prestasi pada siswa kelas X TKJ.
\end{abstract}

Kata Kunci: Kesulitan, Menentukan Persamaan dan Pertidaksamaan nilai mutlak, Pembelajaran Kooperatif Model Jigsaw.

Untuk meningkatkan kualitas dunia pendidikan saat ini sangatlah penting mengingat persaingan yang begitu ketat baik itu dari bangku sekolah sampai dunia kerja , maka tentunya yang menjadi tokoh sentral untuk mewujudkan hal tersebut merupakan tugas bagi seorang tenaga pendidik yang bersentuhan langsung dengan anak didiknya. Peran itu dilaksanakan sebagaimana diharapkan dari seorang guru untuk selalu meningkatkan kompetensi kemampuan, tanggungjawab maupun pengabdian. Dalam dunia pendidikan, profesionalisme seorang guru memegang peranan yang sangat strategis terutama dalam upaya membentuk watak bangsa melalui pengembangan kepribadian dan nilai-nilai yang diinginkanPeran profesionalisme seorang guru sangat dibutuhkan sesuai dengan kemajuan masyarakat modern. Kemajuan ini merupakan tantangan bagi bangsa Indonesia umumnya dan para pendidik khususnya. (Depdiknas, 2003:2). Guru hendaknya menciptakan suasana belajar yang kondusif untuk mendorong keberhasilan siswa. Pencapaian hasil ditentukan oleh kompetensi atau kemampuan guru dalam mengelola interaksi belajar mengajar, dan pencapaian tujuan pembelajaran melalui model pembelajaran. 
Tujuan pendidikan matematika dalam jurnal NCTM (National Council of Teachers mathematics) (Asipa, 2005:6) menggambarkan bahwa pencapaian tujuan pendidikan matematika ini banyak berorientasi pada proses berlangsungnya pembelajaran. Oleh karena itu matematika harus dikelola dengan memperhatikan kemajuan-kemajuan yang dicapai siswa selama proses belajar berlangsung, termasuk penggunaan model pembelajaran yang tepat agar kesulitan siswa dalam belajar dapat diatasi.

Berkaitan dengan hal tersebut, maka usaha yang dilakukan guru dalam pembelajaran matematika adalah memilih suatu model pembelajaran yang dapat memberi perhatian cukup pada kesulitan siswa terhadap konsep dan ide-ide matematika. Adapun hasil observasi peneliti pada tanggal 4 Agustus 2015 terhadap hasil pembelajaran mata pelajaran matematika di kelas X TKJ B SMKN 3 Palu sebagai berikut:

1. Salah satu materi yang dianggap masih sulit oleh sebagian siswa semester satu (ganjil ) adalah Persamaan dan Pertidaksamaan Linear dalam memahami dan menemukan Konsep Nilai Mutlak. Hal ini disebabkan karena kebanyakan siswa belum menguasai konsep dasar, selain itu cara mengajar guru masih menggunakan pembelajaran ekspositori.

2. Kerjasama siswa dalam belajar masih sangat kurang, hal ini disebabkan karena para siswa malu bertanya kepada teman-temannya sendiri dan keaktivan siswa dalam pembelajaran yang pasif karena takut bertanya kepada guru, tidak berani mengeluarkan pendapat akibatnya siswa kurang perhatian untuk mempelajari materi yang disiapkan guru serta motivasi siswa untuk belajar matematika sangat rendah.

Salah satu contoh kesulitan siswa dalam menyelesaikan soal persamaan dan pertidaksamaan dalam nilai mutlak adalah menentukan unsur-unsur dalam nilai mutlak. Siswa kesulitan untuk menentukan himpunan penyelesaian karena kurang memahami konsep dasar operasi hitung yaitu perkalian bilangan negatif dengan bilangan negatif, pengurangan bilangan negatif dengan bilangan positif dan seterusnya. Sehingga meskipun siswa melanjutkan untuk menemukan jawaban, siswa akan mengalami kesalahan.

Kesulitan ataupun kesalahan yang dilakukan oleh siswa disebabkan karena kurangnya pengetahuan dasar yang dimiliki oleh siswa, selain itu tidak adanya saling membantu yang positif antara siswa yang satu dengan siswa yang lain. Saat proses pembelajaran ketika guru menerangkan materi dengan ceramah, di lain pihak siswa hanya mencatat materi yang diajarkan tanpa mau terlibat aktif dalam proses belajar mengajar. Dengan demikian saat guru mengadakan tanya jawab siswa kurang memberikan respon (tanggapan) dan terkesan takut untuk bertanya.

Penggunaan metode ceramah murni mengakibatkan siswa hanya mendengarkan penyampaian materi, sehingga kecenderungan informasi yang didapatkan/diterima kurang dipahami dan mudah lupa. Tanpa adanya suatu pemahaman yang cukup siswa akan kesulitan jika mengerjakan soal-soal latihan terutama soal-soal yang dimodifikasi. Untuk mengatasi kesulitan tersebut maka salah satu model pembelajaran yang cocok adalah model Jigsaw, karena pembelajaran kooperatif model Jigsaw dapat mendorong siswa untuk mau belajar, terlibat secara aktif dalam kegiatan pembelajaran serta saling membantu satu sama lain dalam hal memecahkan kesulitan belajar. Semestinya suasana demikian ini perlu diciptakan dalam 
proses pembelajaran karena dengan suasana tersebut akan memberi peluang kepada seluruh siswa untuk meningkatkan prestasi belajarnya.

Berdasarkan uraian tersebut, maka peneliti merumuskan sebuah masalah tentang Penerapan Pembelajaran Kooperatif Tipe Jigsaw untuk Mengatasi Kesulitan Siswa dalam Menyelesaikan Persamaan Dan Pertidaksamaan Nilai Mutlak pada Kelas X TKJ B SMKN 3 Palu Tahun Pelajaran 2015/2016. Tujuannya untuk mendeskripsikan pembelajaran kooperatif model Jigsaw yang dapat mengatasi kesulitan siswa dalam memahami konsep nilai mutlak.

Secara umum kesulitan dapat diartikan sebagai proses ketidakmampuan. Pengertian ini menggambarkan suatu perubahan perilaku yang tidak rasional. Perubahan seorang siswa dikatakan tidak rasional dalam menyelesaikan soal, apabila siswa tersebut dalam waktu yang ditentukan tidak mampu menyelesaikan dengan baik dan benar. Sebagaimana yang dikemukakan oleh suatu organisasi Teboard Of The Association for Children and Adult with Learning Disabilities (ACALD) dan kemudian dikutip oleh Lovitt (Abdurrahman, 1999:8): "Kesulitan belajar adalah suatu proses ketidakmampuan (kondisi) yang nyata pada orang-orang yang memiliki intelegensi rata-rata hingga superior, yang memiliki sistem sensoris yang cukup dan kesempatan untuk belajar yang cukup pula". The National Joun Committee for Learning Disabilities (NJCLD) mengemukakan definisi kesulitan belajar sebagai berikut:

Kesulitan belajar menunjukkan pada sekelompok kesulitan yang dimanifestasikan dalam bentuk kesulitan yang nyata dalam kemahiran dan penggunaan kemampuan mendengarkan, bercakap-cakap, membaca, menalar, atau kemampuan dalam bidang matematika. Gangguan tersebut instrinsink dan diduga disebabkan adanya disfungsi sistem syaraf pusat. Meskipun suatu kesulitan belajar mungkin terjadi bersamaan dengan adanya kondisi lain yang mengganggu (misalnya gangguan sensoris, tuna grahita, hambatan sosial dan emosional) atau berbagai pengaruh lingkungan. (Misalnya perbedaan budaya, pembelajaran yang tidak tepat, faktor-faktor psikogenik), berbagai hambatan tersebut bukan penyebab atau pengaruh langsung. (Asipa Saha, 2005:11).

Beberapa definisi tentang belajar kooperatif yang dikemukakan oleh para ahli pendidikan yang secara redaksional berbeda namun hakekatnya sama. Definisi belajar kooperatif yang telah dirumuskan oleh Newman dan Artzt (Usman, H.B. 2004:114) yaitu "Cooperative learning is an approach that involves a small group of learners working together as a team to solve a problem, complete a task, a accomplish a common goal".

Definisi ini mengandung pengertian bahwa dalam belajar kooperatif siswa belajar bersama sebagai suatu tim dalam menyelesaikan tugas-tugas kelompok untuk mencapai tujuan bersama. Jadi setiap anggota kelompok memiliki tanggung-jawab bersama untuk keberhasilan kelompoknya. Lebih lanjut Johnson dan Johnson (Usman, H.B. 2004:114) yaitu "cooperative learning is the instructional use of small groups so that student work together to maximize their own and each others learning". Kemudian (Junaedi, 2006:11) mengatakan bahwa "belajar kooperatif merupakan metode dengan melibatkan kelompok kecil siswa saling bekerja sama, saling memberikan atau menukar ide dan bertanggung jawab kepada kelompok mereka disamping dari mereka sendiri”. 
Zamroni (Usman, H.B. 2001:33) mengemukakan manfaat lain dari belajar kooperatif yaitu apabila guru melaksanakan proses belajar dengan menggunakan belajar kooperatif maka dapat mengurangi kesenjangan pendidikan khususnya dalam wujud out-put pada tingkat individu. Disamping itu, berkembangnya kesetiakawanan dan solidaritas sosial di kalangan peserta didik pada gilirannya akan dapat mengurangi ketimpangan dalam wujud input pada tingkat individu. Dengan demikian dapat diharapkan kelak akan muncul generasi baru yang memiliki prestasi akademik yang cemerlang dan juga memiliki kesetiakawanan dan solidaritas sosial yang kuat.

Secara, umum kelompok heterogen lebih banyak disukai dalam pembelajaran kooperatif, hal ini karena (1) kelompok heterogen memberikan kesempatan untuk saling mengajar (peer tutoring) dan saling mendukung, (2) kelompok ini meningkatkan relasi dan interaksi antar ras, agama, etnik dan gender. (3) kelompok heterogen memudahkan pengelolaan kelas karena dengan adanya satu orang yang berkemampuan akademis tinggi, guru mendapat satu asisten untuk setiap orang (Junaedi, 2005:9). Beberapa karakteristik dari pembelajaran kooperatif yaitu:

1. Kelas dibagi atas kelompok-kelompok kecil, dengan anggota kelompok terdiri dari siswa yang heterogen.

2. Siswa belajar dalam kelompok secara kooperatif untuk menguasai materi akademis. Tugas anggota kelompok adalah saling membantu teman kelompoknya untuk mencapai ketuntasan belajar.

3. Penghargaan lebih berorientasi pada penghargaan kelompok dibanding individu.

Junaedi, (2005:10) terdapat enam sintaks atau tahapan dalam pembelajaran kooperatif.

Tahapan pembelajaran kooperatif dapat dilihat pada tabel berikut:

Tabel 1. Sintaksis Pembelajaran Kooperatif

\begin{tabular}{|l|l|}
\hline \multicolumn{1}{|c|}{ Fase } & \multicolumn{1}{c|}{ Tingkah Laku Guru } \\
\hline $\begin{array}{l}\text { Fase 1 } \\
\text { Menyampaikan tujuan dan } \\
\text { memotivasi siswa }\end{array}$ & $\begin{array}{l}\text { Guru menyampaikan semua tujuan pembelajaran } \\
\text { yang ingin dicapai pada pelajaran tersebut dan } \\
\text { memotivasi siswa belajar. }\end{array}$ \\
\hline $\begin{array}{l}\text { Fase 2 } \\
\text { Menyajikan informasi }\end{array}$ & $\begin{array}{l}\text { Guru menyajikan informasi kepada siswa dengan } \\
\text { jalan demonstrasi atau lewat bahan bacaan. }\end{array}$ \\
\hline $\begin{array}{l}\text { Fase 3 } \\
\text { Mengorganisasikan siswa ke dalam } \\
\text { kelompok-kelompok bekerja dan } \\
\text { belajar }\end{array}$ & $\begin{array}{l}\text { Guru menjelaskan kepada siswa bagaimana cara } \\
\text { membentuk kelompok belajar dan membantu setiap } \\
\text { kelompok agar melakukan transisi secara efisien }\end{array}$ \\
\hline $\begin{array}{l}\text { Fase } 4 \\
\text { Membimbing kelompok bekerja dan } \\
\text { belajar }\end{array}$ & $\begin{array}{l}\text { Guru membimbing kelompok-kelompok belajar } \\
\text { pada saat mereka mengerjakan tugas mereka. }\end{array}$ \\
\hline $\begin{array}{l}\text { Fase 5 } \\
\text { Evaluasi }\end{array}$ & $\begin{array}{l}\text { Guru mengevaluasi hasil belajar tentang materi } \\
\text { yang telah dipelajari atau masing-masing kelompok } \\
\text { mempresentasikan hasil kerjanya. }\end{array}$ \\
\hline $\begin{array}{l}\text { Fase 6 } \\
\text { Memberikan penghargaan }\end{array}$ & $\begin{array}{l}\text { Guru mencari cara-cara untuk menghargai baik } \\
\text { upaya maupun hasil belajar individu dan kelompok }\end{array}$ \\
\hline
\end{tabular}


Pembelajaran artinya cara menjadikan seseorang belajar. Sedangkan kooperatif Jigsaw artinya kerja sama sebagai sifat. Berdasarkan pengertian tersebut, dapat diambil kesimpulan bahwa pendekatan pembelajaran kooperatif jigsaw adalah salah satu. Untuk kegiatan yang dilakukan seseorang (guru) yang membuat orang lain (siswa) saling membantu dalam belajar guna mencapai tujuan bersama.

Model yang digunakan dalam penelitian ini adalah Pembelajaran Kooperatif Model Jigsaw dalam mengatasi kesuliatan siswa memahami konsep Persamaan dan Pertidaksamaan Nilai Mutlak. Model pembelajaran Jigsaw merupakan salah satu variasi model Collaborative Learning yaitu proses belajar kelompok dimana setiap anggota menyumbangkan informasi, pengalaman, ide, sikap, pendapat, kemampuan, dan keterampilan yang dimilikinya, untuk secara bersama-sama saling meningkatkan pemahaman seluruh anggota. Pembelajaran kooperatif tipe Jigsaw adalah suatu tipe pembelajaran kooperatif yang terdiri dari beberapa anggota dalam satu kelompok yang bertanggung jawab atas penguasaan bagian materi belajar dan mampu mengajarkan materi tersebut kepada anggota lain dalam kelompoknya (Sudrajat, 2008:1). Model pembelajaran Jigsaw merupakan strategi yang menarik untuk digunakan jika materi yang akan dipelajari dapat dibagi menjadi beberapa bagian dan materi tersebut tidak mengharuskan urutan penyampaian. Kelebihan strategi ini adalah dapat melibatkan seluruh peserta didik dalam belajar dan sekaligus mengajarkan kepada orang lain (Zaini, 2008:56). Oleh karena itu, untuk mencapai tujuan pribadi mereka anggota kelompok harus membantu teman kelompoknya untuk melakukan maksimum bila menuju satu tujuan yang sama seperti yang mereka terapkan dalam pembelajaran kooperatif Jigsaw, upaya mereka justru membantu teman kelompoknya untuk berhasil. Pada pembelajaran kooperatif Jigsaw siswa saling mendorong untuk belajar, dan menerapkan norma-norma yang menunjang pencapaian hasil belajar yang tinggi, sehingga dapat menjawab permaslahan tersebut diatas.

\section{METODE PENELITIAN}

Metode yang dipakai dalam penelitian ini merupakan Penelitian tindakan kelas yang mengkolaborasikan prosedur penelitian dengan tindakan dan berusaha mengkaji , merefleksi suatu model belajar untuk tujuan meningkatkan kualitas pembelajaran. Penelitian ini dilaksanakan dalam dua siklus dan mengacu kepada model Kemmis dan Mc.Taggart (Usman H.B, 2001:34) yang terdiri dari komponen yaitu perencanaan, tindakan, pengamatan, (observasi), dan refleksi.

Adapun teknik pengambilan datanya dengan pendekatan kwalitatif. Pendekatan kwalitatif menurut Bogdan dan Taylor (Maleong, 1990:22) adalah suatu prosedur penelitian yang menghasilkan data yang deskriptif berupa kata-kata tertulis atau lisan dari orang-orang dan perilaku yang diamati.

1. Jenis Data adalah (1) hasil pekerjaan siswa yang meliputi : tes awal, tes setiap akhir siklus pembelajaran dan tes akhir tindakan, (2) hasil observasi terhadap aktivitas siswa dan guru, (3) hasil wawancara subjek penelitian.

2. Cara Pengumpulan Data adalah sebagai berikut: 
a. Penilaian Kinerja adalah untuk mengukur dan mengetahui kesulitan siswa terhadap persamaan dan pertidaksamaan nilai mutlak dengan menguji siswa dengan memberikan tes secara tertulis. Siswa dituntut mendemonstrasikan pengetahuan dan keterampilan yang telah dipelajarinya pada berbagai situasi nyata dan konteks tertentu. Tes awal atau tes yang diberikan sebelum tindakan bertujuan untuk mengumpulkan informasi tentang pengetahuan awal siswa mengenai materi prasyarat persamaan dan pertidaksamaan nilai mutlak. Tes pada setiap akhir tindakan bertujuan untuk memperoleh data tentang tingkat kesulitan siswa memahami persamaan dan pertidaksamaan nilai mutlak yang diberikan setelah diajar dengan menerapkan pembelajaran kooperatif model Jigsaw.

b. Wawancara adalah untuk menelusuri secara mendalam sejauh mana tingkat kesulitan siswa terhadap persamaan dan pertidaksamaan nilai mutlak yang diperoleh melalui tes wawancara bersifat klinis, karena pertanyaan-pertanyaan yang diajukan pada saat wawancara bersumber dari hasil pekerjaan siswa. Selanjutnya pada saat wawancara berlangsung, dilakukan perbaikan-perbaikan tentang kesalahan yang dilakukan dalam mengerjakan soal.

c. Pengamatan sistematis yang dimaksud adalah untuk mengamati aktivitas siswa dan guru dalam kelas selama proses pembelajaran berlangsung, dan dari data yang diperoleh dari pengamatan dicatat dalam lembar pengamatan (observasi).

d. Penilaian Diri bertujuan untuk merefleksikan dan menginterpretasikan dampak dari aktivitas pembelajaran persamaan dan pertidaksamaan nilai mutlak dengan menerapkan pembelajaran kooperatif model Jigsaw.

e. Penilaian Minat dan sikap dilakukan untuk mengetahui bagaimana minat dan sikap siswa terhadap matematika khususnya persamaan dan pertidaksamaan nilai mutlak dengan menerapkan pembelajaran kooperatif model Jigsaw

f. Catatan Lapangan adalah untuk memperoleh data mengenai hal-hal yang terjadi, selama pembelajaran berlangsung yang tidak terekam dalam lembar observasi.

Sedangkan langkah-langkah yang dilakukan untuk menganalisa data dalam penelitian ini menggunakan model alir pada Miles dan Huberman (Atma Vicharys, 2006:21), yaitu (1) mereduksi data, (2) menyajikan data, dan (3) menyimpulkan data. Karena penelitian ini adalah penelitian tindakan yang bersifat kualitatif, maka teknik analisis data dilakukan sejak awal sampai penelitian berakhir yaitu sebagai berikut:

1. Mereduksi data

Mereduksi data diartikan sebagai proses kegiatan menyeleksi, memfokuskan, dan menyederhanakan data sejak awal pengumpulan data sampai pengumpulan laporan.

2. Penyajian data 
Penyajian data dilakukan secara naratif, sekumpulan informasi yang telah dipelajari dari hasil reduksi, sehingga dapat memberikan kemungkinan penarikan kesimpulan dan pengambilan tindakan. Data yang telah disajikan tersebut sebelumnya dibuat penafsiran dan evaluasi untuk membuat perencanaan tindakan selanjutnya.

3. Penarikan kesimpulan

Dimaksudkan untuk memberikan kesimpulan terhadap hasil penafsiran dan evaluasi. Penarikan kesimpulan merupakan pengungkapan akhir dari hasil penelitian.

Analisis data hasil observasi aktivitas siswa menggunakan analisis prosentase skor. Selanjutnya dihitung persentase rata-rata dengan rumus:

Persentase nilai rata-rata $(N R)=\frac{\text { Jumlah Skor }}{\text { Jumlah Skor Ideal }} \times 100 \%$

Kriteria taraf keberhasilan tindakan dapat ditentukan sebagai berikut:

$84 \%<\mathrm{NR} \leq 100 \% \quad$ : sangat baik

$74 \%<\mathrm{NR} \leq 84 \% \quad:$ baik

$64 \%<\mathrm{NR} \leq 74 \% \quad:$ cukup

$54 \%<\mathrm{NR} \leq 64 \% \quad:$ kurang

$84 \%<\mathrm{NR} \leq 54 \% \quad$ : sangat kurang $\quad$ (Depdiknas, 2004:12).

Kegiatan-kegiatan yang dilakukan pada siklus pertama akan diulang pada siklus berikutnya setelah memperoleh refleksi dari siswa sebagai subyek penelitian. Setiap akhir siklus akan dilakukan tes untuk mengukur penguasaan konsep dasar matematika. Pada siklus dua akan dikembangkan tahapan-tahapan yang ada pada siklus pertama dengan saran yang dianjurkan oleh siswa, seperti halnya perlakuan pada siklus dua diharapkan akan lebih baik dari nilai tes pada siklus pertama

Setting penelitian ini dilaksanakan di SMKN 3 Palu, dan kelas yang dijadikan penelitian adalah siswa kelas X. Subyek penelitian ini adalah siswa kelas X TKJ B yang mengikuti mata pelajaran matematika semester ganjil tahun ajaran 2015/2016 dengan jumlah siswa 33 orang yang terdiri atas 28 siswa laki-laki dan 5 orang perempuan.

Rencana tindakan pembelajaran yang berlangsung sebanyak dua (2) kali dalam dua siklus dengan masing-masing siklus terdiri dari satu tindakan. Setiap tindakan pembelajaran menggunakan langkah-langkah pembelajaran kooperatif model Jigsaw. Pada tindakan pembelajaran I dan tindakan pembelajaran II waktu yang digunakan masing-masing 2x45 menit dan 3x45 menit. Penelitian ini dimulai sejak tanggal 07 s/d 25 Agustus 2015. Indikator keberhasilan tindakan dilihat dari tingkat pencapaian kemampuan siswa dalam menyelesaikan soal menentukan penyelesaian persamaan dan pertidaksamaan nilai mutlak .

Ukuran keberhasilan penelitian ini dapat dilihat dari:

a. Hasil observasi aktivitas siswa dan pengelolaan pembelajaran yang berada dalam kualifikasi baik.

b. Hasil belajar siswa mencapai:

1. Rata-rata kategori baik $\geq 75 \%$.

2. Daya serap (penguasaan bahan ajar) kategori baik $\geq 60 \%$. 
3. Ketuntasan belajar (penguasaan kompetensi) kategori baik $\geq 80 \%$.

4. Rata-rata peningkatan (kontribusi) perlakuan terhadap hasil belajar kategori baik.

Daya Serap Individu $=\frac{\text { Jumlah Skor yang Diperoleh Siswa }}{\text { Skor Maksimal Soal }} \times 100 \%$

Daya Serap Klasikal $=\frac{\text { Skor Total yang Diperoleh Siswa }}{\text { Skor Ideal Seluruh Siswa }} \times 100 \%$

Persentase Tuntas Klasikal $=\frac{\text { Jumlah Siswa yang Tuntas }}{\text { Jumlah Siswa Seluruhnya }} \times 100 \%$

(Depdiknas, 2004:12)

Kriteria keberhasilan tindakan dianggap berhasil jika diperoleh persentase daya serap individual $\geq 75 \%$ dan persentase ketuntasan klasikal $\geq 80 \%$.

\section{HASIL DAN PEMBAHASAN}

Kegiatan awal yang dilakukan peneliti sebelum melakukan tindakan yaitu mengadakan observasi siswa dalam mengikuti pelajaran. Observasi dilakukan untuk mengetahui situasi dan kondisi dari proses pembelajaran. Selain itu untuk memperoleh informasi-informasi yang berkaitan dengan hal-hal yang akan diteliti. Observasi siswa dilakukan pada kelas yang akan menjadi subyek penelitian. Peneliti memberitahukan pada siswa bahwa sebelum melakukan pembelajaran akan dilakukan tes awal untuk dapat mengetahui sampai sejauh mana pemahaman siswa terhadap konsep persamaan dan pertidaksamaan nilai mutlak .

Penerapan Model pembelajaran Kooperatif Jigsaw merupakan salah satu alternative yang digunakan peniliti untuk meningkatkan pemahaman siswa terhadap konsep - konsep matematika teutama pada Persamaan dan Pertidaksamaan Nilai Mutlak. Dalam pelaksanaan model ini dapat memberikan kontribusi positif terhadap peningkatan pemahaman siswa dalam konsep tersebut .

Berikut hasil tes pencapaian nilai matematika oleh siswa kelas X TKJ B SMKN 3 Palu yang disajikan dalam tabel siklus penelitian.

Tabel 2. Distribusi Nilai Hasil Tes Siswa

\begin{tabular}{|c|c|c|c|c|c|}
\hline \multirow[b]{2}{*}{ NO. } & \multirow{2}{*}{$\begin{array}{l}\text { NAMA } \\
\text { SISWA }\end{array}$} & \multicolumn{3}{|c|}{ NILAI TES } & \multirow[b]{2}{*}{$\begin{array}{c}\text { TES } \\
\text { AKHIR }\end{array}$} \\
\hline & & $\begin{array}{c}\text { TES } \\
\text { AWAL }\end{array}$ & $\underset{\text { I }}{\text { SIKLUS }}$ & $\begin{array}{c}\text { SIKLUS } \\
\text { II }\end{array}$ & \\
\hline 1 & AAI & 40 & 78 & 75 & 77 \\
\hline 2 & CMA & 75 & 75 & 75 & 82 \\
\hline 3 & CKR & 42 & 65 & 75 & 72 \\
\hline 4 & DA & 42 & 75 & 75 & 79 \\
\hline 5 & DM & 40 & 50 & 55 & 78 \\
\hline
\end{tabular}


42 AKSIOMA, Volume 10 Nomor 1, Maret 2021

\begin{tabular}{|c|c|c|c|c|c|}
\hline 6 & FD & 75 & 75 & 75 & 77 \\
\hline 7 & FDS & 50 & 60 & 58 & 70 \\
\hline 8 & FFB & 45 & 55 & 55 & 77 \\
\hline 9 & FI & 45 & 76 & 75 & 80 \\
\hline 10 & GA & 45 & 45 & 75 & 78 \\
\hline 11 & GIB & 45 & 45 & 75 & 77 \\
\hline 12 & IRS & 43 & 52 & 57 & 75 \\
\hline 13 & IA & 43 & 75 & 58 & 75 \\
\hline 14 & ISP & 42 & 50 & 61 & 75 \\
\hline 15 & IHW & 42 & 55 & 50 & 75 \\
\hline 16 & MRB & 75 & 77 & 75 & 75 \\
\hline 17 & MSP & 80 & 82 & 85 & 89 \\
\hline 18 & MPU & 45 & 65 & 52 & 73 \\
\hline 19 & MRA & 45 & 65 & 75 & 75 \\
\hline 20 & MR & 75 & 75 & 75 & 78 \\
\hline 21 & $\mathrm{MZ}$ & 75 & 75 & 75 & 75 \\
\hline 22 & MAH & 75 & 75 & 75 & 77 \\
\hline 23 & MF & 45 & 60 & 60 & 70 \\
\hline 24 & $\mathrm{OA}$ & 40 & 65 & 55 & 78 \\
\hline 25 & $\mathrm{RR}$ & 45 & 60 & 50 & 65 \\
\hline 26 & $\mathrm{RR}$ & 45 & 75 & 75 & 63 \\
\hline 27 & $S$ & 50 & 55 & 75 & 75 \\
\hline 28 & SR & 75 & 80 & 85 & 80 \\
\hline 29 & $\mathrm{UH}$ & 50 & 55 & 75 & 75 \\
\hline 30 & VSL & 50 & 75 & 60 & 75 \\
\hline 31 & YR & 45 & 55 & 65 & 78 \\
\hline 32 & $\mathrm{YZ}$ & 45 & 75 & 75 & 78 \\
\hline \multirow[t]{2}{*}{33} & YK & 50 & 75 & 75 & 78 \\
\hline & JUMLAH & 24,24 & 48.48 & 60.61 & 81.82 \\
\hline
\end{tabular}

Berdasarkan data pada tabel diatas ditemukan bahwa pada tes awal diperoleh bahwa skor tertinggi yang dicapai siswa adalah 80, skor yang terendah dicapai siswa adalah 40, dan nilai rata-ratanya atau daya serap siswa adalah 52,24\%. Dan persentase ketuntasan klasikalnya adalah $24,24 \%$. Daya serap tersebut menggambarkan bahwa kemampuan siswa terhadap materi masih rendah. Dari hasil tes tersebut juga menunjukkan bahwa secara klasikal siswa masih mengalami kesulitan untuk menguasai materi prasyarat. 
Pada siklus I hasil tes mengalami peningkatan yaitu ada 12 siswa atau $65.91 \%$ dinyatakan tuntas dengan ketuntasan klasikal mencapai $48.48 \%$ dengan skor tertinggi 82 dan terendah 50. Setelah dilakukan perbaikan maka pada siklus II hasil tes siswa memperoleh 20 siswa atau $68.36 \%$ tuntas dengan capaian ketuntasan klasikal $60.61 \%$ dengan skor tertinggi 85 dan terendah 50. Ini membuktikan terjadi perubahan yang cukup baik terhadap perkembangan pemahaman siswa dengan menggunakan Model pembelajaran Kooperatif Tipe Jigsaw.

Setelah pelaksanaan tindakan yang dilakukan selama 2 siklus berakhir maka diadakan tes akhir tindakan. Tes akhir tindakan berbentuk uraian yang terdiri dari 4 butir soal dengan materi, sub pokok bahasan menentukan himpunan penyelesaian persamaan dan pertidaksamaan nilai mutlak. Tujuan pemberian tes akhir tindakan adalah untuk memperoleh data tentang sejauhmana tingkat kesulitan siswa dalam menentukan himpunan penyelesaian persamaan dan pertidaksamaan nilai mutlak yang diberikan setelah diajar dengan pembelajaran kooperatif model Jigsaw.. Dari hasil analisis dapat dilihat skor tertinggi yang dicapai siswa adalah 89 dan skor terendah adalah 63. Nilai rata-rata atau daya serap klasikal sebesar $75,88 \%$, dan persentase ketuntasan klasikal sebesar 81,82 \%. Hasil tersebut menunjukkan bahwa pada umumnya siswa telah mengetahui konsep dasar operasi hitung, sehingga kesulitan siswa dapat teratasi.

Selanjutnya setelah itu dilakukan wawancara akhir tindakan.Tujuan dilakukan wawancara adalah untuk melihat sejauhmana tingkat kesulitan siswa dalam menentukan himpunan penyelesaian persamaan dan pertidaksamaan nilai mutlak. Wawancara dilakukan pada kelima subyek penelitian yang berpedoman pada hasil tes akhir siswa untuk mengetahui penyebab kegagalan subyek dalam menyelesaikan soal. Dari hasil wawancara diperoleh bahwa siswa senang belajar kooperatif model Jigsaw dan kesalahan yang dilakukan siswa pada umumnya karena kurangnya ketelitian siswa dalam mengerjakan soal.

\section{KESMPULAN}

1. Penerapan pembelajaran kooperatif model Jigsaw dapat mengatasi kesulitan siswa dalam menentukan Penerapan Pembelajaran Kooperatif Tipe Jigsaw untuk Mengatasi Kesulitan Siswa belajar dalam menentukan Himpunan Penyelesaian Persamaan Dan Pertidaksamaan Nilai Mutlak pada Kelas X TKJ B SMKN 3 Palu.

2. Kerjasama siswa dalam model Jigsaw berlangsung sangat baik ditinjau dari segi kemampuan ataupun perbedaan suku dan agama. Serta siswa menemukan pengetahuan menghargai pendapat orang lain.

3. Siswa mampu berinteraksi dengan baik ke sesama anggota kelompok, sehingga kesulitankesulitan dalam belajar dapat teratasi.

4. Model Jigsaw mampu meningkatkan partisipasi siswa secara aktif baik antara guru dengan siswa maupun siswa dengan siswa.

\section{SARAN}


44 AKSIOMA, Volume 10 Nomor 1, Maret 2021

1. Berdasarkan hasil penelitian yang mengungkap bahwa penerapan belajar kelompok dapat mengatasi kesulitan siswa dalam menentukan Penerapan Pembelajaran Kooperatif Tipe Jigsaw untuk Mengatasi Kesulitan Siswa belajar dalam menentukan Himpunan Penyelesaian Persamaan Dan Pertidaksamaan Nilai Mutlak, kiranya belajar kooperatif ini dapat dipertimbangkan aplikasinya pada pembelajaran di sekolah.

2. Karena pelaksanaan pembelajaran kooperatif model Jigsaw memerlukan waktu yang agak lama maka diinformasikan pelaksanaan pembelajaran terutama pada pembentukan kelompok ditentukan pada waktu di luar jam pelaksanaan pembelajaran agar tidak menyita waktu yang telah ditentukan.

3. Dalam menentukan Himpunan Penyelesaian Persamaan Dan Pertidaksamaan Nilai Mutlak, kiranya guru matematika lebih memfokuskan penjelasannya tentang kecermatan siswa dalam menggunakan sifat-sifat nilai mutlak terutama penggunaanya dalam persamaan dan pertidaksamaan .

4. Dengan penerapan pembelajaran kooperatif model Jigsaw yang dapat mengatasi kesulitan siswa dalam belajar matematika, kiranya penerapannya dapat dimasyarakatkan oleh guru matematika dalam rangka peningkatan mutu pendidikan matematika di sekolah.

\section{DASTAR PUSTAKA}

Abdurrahman. 1999. Pendidikan Bagi Anak Berkesulitan Belajar. Aneka Cipta.

Asipa Saha. 2005. Mengatasi Kesulitan Belajar Siswa Kelas II D SMP Negeri 2 Dolo dalam Memahami Belah Ketupat dengan Menggunakan Alat Peraga. Palu: FKIP Untad.

Depdiknas. 2003. Penelitian Tindakan Kelas. Bahan Ajar Pembekalan Guru Bantu.

Depdiknas. 2004. Penilaian. Depdiknas. Jakarta.

Hadisuprapto. 1986. Petunjuk Pelaksanaan Proses Belajar Mengajar. Departemen Kebudayaan Jakarta.

Jatmiko Budi. 2003. Penelitian Tindakan Kelas. Jakarta: Depdiknas.

Junaedi. 2006. Penerapan Pembelajaran Kooperatif Tipe STAD Untuk Meningkatkan Hasil Belajar Fisika Siswa Kelas VII SMP Negeri 1 Palu (PTK Menggunakan Penelitian Otentik). Palu: FKIP Untad.

Maleong, L. J. 1990. Metode Penelitian Kualitatif. Remaja Karya. Bandung.

Negoro \& Harahap. 2000. Ensiklopedia Matematika. Ghalia Indonesia. Anggota IKAPI. 
Siswanto. 2003. Pelajaran Matematika 1A Untuk Kelas 1 SMU Semester 1. PT. Tiga Serangkai Mandiri. Solo.

Usman, HB. 2001. Aplikasi Belajar Kooperatif Untuk Memahami Konsep Limit Fungsi Suatu Variabel Real. Tesis tidak diterbitkan.

Usman, HB. 2004. Strategi Pembelajaran Kontemporer Suatu Pendekatan Model. Cisarua: Direktorat Jendral Pendidikan Tinggi Departemen Pendidikan Nasional.

Wirodikromo Sartono. 2004. Matematika untuk SMA Jilid I Kelas X Semester I. Penerbit Erlangga. Ciracas, Jakarta.

Yusuf. 2003. Kualitas Proses dan Hasil Belajar Biologi Melalui Pengajaran dengan Model Pembelajaran Kooperatif Tipe Jigsaw pada Madrasah Aliyah Ponpes Nurul Haram Lombok Barat NTB. Tesis tidak diterbitkan. Program Pascasarjana. Universitas Negeri Surabaya. Surabaya. 